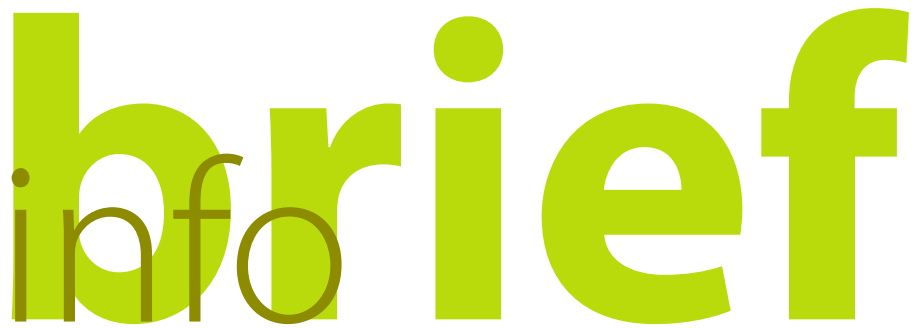

\title{
Actors and landscape changes in tropical Latin America Challenges for REDD+ design and implementation
}

\author{
Pablo Pacheco ${ }^{1}$, Mariel Aguilar-Støen², Jan Börner ${ }^{1}$, Andres Etter ${ }^{3}$, Louis Putzel' ${ }^{1}$, and Maria del Carmen Vera Diaz ${ }^{4}$
}

\section{Key points}

- Five dominant trends are occurring in tropical Latin America with implications for land use change: (1) rapid growth of agribusiness, (2) expansion and modernisation of traditional cattle ranching, (3) slow growth of small-scale agriculture, (4) logging in production forest frontiers and (5) resurgence of traditional agro-extractive economies.

- These trends are driven by global markets and national policies, and have significant impacts on landscape change, with diverse associated trade-offs between agricultural development and forest conservation, and impacts on people's livelihoods.

- Agribusiness expansion helps create economic growth but leads to deforestation and tends to concentrate incomes. Cattle ranching demands extensive land surface and creates few jobs, which also leads to forest conversion. Peasant agriculture creates jobs and local income but has diverse impacts on deforestation. Indigenous and community lands help to protect forests, but generate few opportunities for livelihoods improvement. Forest concessions do little damage to forests but concentrate incomes among a few people.

- These contrasting outcomes call for differentiated policy measures for agricultural development, forest conservation and poverty alleviation. There is a need to manage the expansion of large-scale agribusiness and ranching, whilst improving the economic options of smallholders, indigenous groups and other disadvantaged people.

- REDD+ schemes may help to reduce pressures on forests by compensating land users for foregone benefits. However, there is a need to balance efficiency in reducing emissions from deforestation and equity in the distribution of economic incentives.

- No 'one-size-fits-all' approach to REDD+ could possibly deliver both cost-effectiveness and equity across such diverse landscapes and groups of actors. Whilst some REDD+ activities should target deforestation hotspots at the forest frontier, national strategies must remain inclusive and ensure that benefits and costs are shared among diverse stakeholder groups according to criteria of political fairness.

- REDD+ thus must go far beyond the compensation of land users' opportunity costs in high-pressure areas. It will need to address some of the underlying structural reasons for resource overuse and underdevelopment in tropical forest areas.

\section{Introduction}

Growth in domestic consumption and exports has occurred at the expense of tropical forestlands (Gibbs et al. 2010). The trade-off between development and conservation in tropical landscapes has been widely debated (Lee and Barrett 2001). As the role of forests in climate change mitigation has become ever more irrefutable, the trade-off debate has gained momentum. A number of perspectives on developmentconservation trade-offs coexist. Whereas some argue that promoting intensive and large-scale agriculture could lead to greater economic growth, reduce deforestation and improve land use efficiency (Grau and Aide 2008), others claim that

1 Center for International Forestry Research (CIFOR), Bogor, Indonesia

2 University of Oslo, Centre for Development and the Environment, Oslo, Norway 3 Pontificia Universidad Javeriana, Departamento de Ecología y Territorio, Bogotá, Colombia

4 Global Development and Environment Institute (GDAE), Tufts University, Medford, MA, USA. securing tenure rights of forest-dependent communities constitutes an effective way to enhance local people's livelihoods whilst protecting forests (Bray et al. 2005). Others suggest that the establishment of diversified production systems has positive impacts on smallholders' welfare (Barham et al. 1999). We argue that the above views complement each other, but that managing the trade-offs between agricultural development and forest conservation will require a more comprehensive understanding of the different social and economic dynamics taking place across the diverse landscapes in tropical Latin America.

Five trends are currently occurring in rural landscapes in tropical Latin America, each of which is associated with different socialactor contexts and related landscape outcomes:

- rapid market-driven growth of agribusiness (medium- and large-scale farmers);

- expansion and modernisation of traditional cattle ranching (medium- and large-scale ranchers); 
- slow growth of small-scale agriculture (small-scale farmers);

- logging in production forest frontiers (logging companies and small-scale loggers); and

- resurgence of agro-extractive economies (indigenous people and traditional communities).

In tropical landscapes in Latin America, the design of schemes for reduction of emissions from deforestation and forest degradation and enhancing carbon stocks (REDD+) should acknowledge these diverse trends. This recognition is necessary because REDD+ implementation will influence which development paths - with their likely different effects on actors and landscape change-will prevail.

\section{Diverse actors in tropical Latin America}

About 109 million people live in rural areas in Latin America. The rural population comprises 5 different groups: (1) indigenous people, (2) traditional subsistence smallholders, (3) small-scale farmers, (4) large-scale farmers and ranchers and (5) loggers and timber companies (Table 1). The first 2 groups practise mixed subsistence and commercial agriculture, and are marginally connected to markets. The smallholders, including colonists, have developed diversified production systems with various degrees of specialisation. In turn, large-scale farmers are engaged in commercial production, tend to control significant tracts of land and often have good access to markets and financial resources. The last group comprises independent loggers and logging companies, with different scales of operation, which rely on timber extraction for their income. Finally, an important number of people are also engaged in processing, trade and provision of services linked to activities being developed in these landscapes.

It is important to distinguish between actors: what happens to land and forest resources depends to a large extent on who owns these resources, as each actor group tends to use the resources in different ways and with different objectives. The next section explores some of the main trends of landscape transformation for the region as a whole. This sets the stage for the assessment of the different pathways of landscape change associated with each of the actors described above.

\section{Factors shaping landscape transformation}

Net annual deforestation rates over the period 1990-2005 were significant in both Mesoamerica and South America ( $0.71 \%$ and $0.47 \%$, respectively). They then tended to decrease during the period 2005-2010, although the magnitude of deforestation remains higher in South America. It is

Table 1. Types of forest-based livelihoods and associated attributes of forest use

\begin{tabular}{|c|c|c|c|c|c|}
\hline \multirow[t]{2}{*}{ Type of social actor } & \multicolumn{5}{|c|}{ Attributes linked to the type and objectives of land management } \\
\hline & $\begin{array}{l}\text { Land use and } \\
\text { management }\end{array}$ & $\begin{array}{l}\text { Land use } \\
\text { objectives }\end{array}$ & $\begin{array}{l}\text { Factors that } \\
\text { affect land use } \\
\text { decisions }\end{array}$ & $\begin{array}{l}\text { Main type of } \\
\text { land use }\end{array}$ & $\begin{array}{l}\text { Forest income as } \\
\text { share of total income } \\
\text { of actor group }\end{array}$ \\
\hline Indigenous people & $\begin{array}{l}\text { Hunting, } \\
\text { gathering and } \\
\text { agriculture }\end{array}$ & $\begin{array}{l}\text { Largely } \\
\text { subsistence } \\
\text { oriented }\end{array}$ & $\begin{array}{l}\text { Family size and } \\
\text { availability of } \\
\text { labour }\end{array}$ & $\begin{array}{l}\text { Capture and } \\
\text { collection of forest } \\
\text { fauna and flora, } \\
\text { and agriculture }\end{array}$ & High \\
\hline $\begin{array}{l}\text { Traditional } \\
\text { subsistence } \\
\text { smallholders }\end{array}$ & $\begin{array}{l}\text { Shifting } \\
\text { agriculture }\end{array}$ & $\begin{array}{l}\text { Predominantly for } \\
\text { subsistence }\end{array}$ & $\begin{array}{l}\text { Family size and } \\
\text { availability of } \\
\text { labour }\end{array}$ & $\begin{array}{l}\text { Food production } \\
\text { in land restored by } \\
\text { forest fallows }\end{array}$ & Medium \\
\hline Small-scale farmers & $\begin{array}{l}\text { Small-scale } \\
\text { sedentary } \\
\text { agriculture }\end{array}$ & $\begin{array}{l}\text { Mixed goals of } \\
\text { subsistence and } \\
\text { cash income }\end{array}$ & $\begin{array}{l}\text { Access to labour } \\
\text { influenced by } \\
\text { household } \\
\text { lifecycle, and } \\
\text { availability of land, } \\
\text { capital and markets }\end{array}$ & $\begin{array}{l}\text { Mainly agricultural } \\
\text { production under } \\
\text { diversified systems }\end{array}$ & Low to medium \\
\hline $\begin{array}{l}\text { Large-scale farmers } \\
\text { and ranchers }\end{array}$ & $\begin{array}{l}\text { Large-scale } \\
\text { agriculture and } \\
\text { ranching }\end{array}$ & $\begin{array}{l}\text { Profit } \\
\text { maximisation }\end{array}$ & $\begin{array}{l}\text { Access to land, } \\
\text { availability of } \\
\text { capital and } \\
\text { market access and } \\
\text { conditions }\end{array}$ & $\begin{array}{l}\text { Often agriculture } \\
\text { under intensive, } \\
\text { and ranching } \\
\text { under extensive } \\
\text { production } \\
\text { systems }\end{array}$ & None to low \\
\hline $\begin{array}{l}\text { Loggers and timber } \\
\text { companies }\end{array}$ & $\begin{array}{l}\text { Logging, could } \\
\text { be linked to land } \\
\text { speculation goals }\end{array}$ & $\begin{array}{l}\text { Profit } \\
\text { maximisation }\end{array}$ & $\begin{array}{l}\text { Access to timber, } \\
\text { and availability of } \\
\text { capital and markets }\end{array}$ & $\begin{array}{l}\text { Selective logging } \\
\text { and marketing of } \\
\text { valuable timber } \\
\text { species }\end{array}$ & High \\
\hline
\end{tabular}




\section{Table 2. Characteristics of stylised landscapes in tropical Latin America}

\begin{tabular}{|c|c|c|c|c|}
\hline \multirow[t]{2}{*}{ Type of landscape } & \multicolumn{4}{|c|}{ Attributes associated with landscape type } \\
\hline & Area with forest & Social actors & Land tenure & Access to markets \\
\hline $\begin{array}{l}\text { Agricultural lands } \\
\text { dominated by } \\
\text { agribusiness }\end{array}$ & Small & $\begin{array}{l}\text { Medium- and large-scale } \\
\text { farmers }\end{array}$ & Secure, clear rights & Good \\
\hline $\begin{array}{l}\text { Pasture lands dominated } \\
\text { by extensive cattle } \\
\text { ranching }\end{array}$ & Small & $\begin{array}{l}\text { Medium- and large-scale } \\
\text { ranchers }\end{array}$ & $\begin{array}{l}\text { Relatively secure rights } \\
\text { but contested in new } \\
\text { frontiers }\end{array}$ & Relatively good \\
\hline $\begin{array}{l}\text { Forest-agriculture } \\
\text { mosaics under diversified } \\
\text { land uses }\end{array}$ & $\begin{array}{l}\text { Relatively small_forest } \\
\text { scattered in agricultural } \\
\text { lands_-but stable }\end{array}$ & $\begin{array}{l}\text { Peasants and migrant } \\
\text { colonists }\end{array}$ & $\begin{array}{l}\text { Secure; rights can be } \\
\text { relatively clear through } \\
\text { de facto regimes }\end{array}$ & Relatively good \\
\hline $\begin{array}{l}\text { Frontier areas with } \\
\text { dominance of logging }\end{array}$ & $\begin{array}{l}\text { Relatively large, but } \\
\text { decreasing }\end{array}$ & $\begin{array}{l}\text { Timber companies, } \\
\text { informal loggers and } \\
\text { migrant peasants }\end{array}$ & Insecure & Relatively poor \\
\hline $\begin{array}{l}\text { Areas beyond the } \\
\text { agricultural frontier with } \\
\text { local populations }\end{array}$ & Large and relatively stable & $\begin{array}{l}\text { Indigenous people } \\
\text { and other traditional } \\
\text { smallholders }\end{array}$ & $\begin{array}{l}\text { Insecure, though } \\
\text { progress in collective } \\
\text { titling }\end{array}$ & Poor \\
\hline
\end{tabular}

Source: Adapted from Chomitz (2007)

noteworthy that total annual deforestation for Latin America as a whole shrunk from about 5 million ha in 2005 to 4 million ha in 2010 (FAO 2010). These data, however, mask the trends of secondary forest regrowth, which are particularly significant in some landscapes in Mesoamerica, mainly in Costa Rica, El Salvador and the Pacific regions of Panama and Nicaragua (Kaimowitz 2008). There are some trends of forest regrowth in some specific landscapes in South America also, although it is less advanced (Grau and Aide 2008).

In Mesoamerica, decreasing deforestation rates and, in some cases, forest transition trends are related to broader processes of rural-urban migration, and occasionally significant migration flows to the USA with increased remittances supporting local rural economies (Rigg 2006). In contrast, in South America, the rural population tends to decrease mainly as a result of more rapid urbanisation and greater migration from rural areas to the cities (Carr et al. 2009), although these trends are less dramatic in a few countries (e.g. Bolivia, Colombia, Paraguay and Peru ). Despite urbanisation and migration into cities, some degree of migration continues into rural tropical lands, particularly in the Andean Amazon countries and Brazil. In some cases, urban residents are often not completely absent from rural areas but remain members of multi-sited households and continue to participate in rural-urban networks (Padoch et al. 2008).

There is an increasing tension in the public policies applied by the governments in the region. Some policies increase pressures on forests, such as those supporting the development of the agribusiness sector and large-scale investment in infrastructure development (e.g. through the Initiative for the Integration of Regional Infrastructure in South
America, or IIRSA). Other policies lead to forest conservation, such as those allocating forests for conservation, recognising tenure rights of indigenous and other local people and applying stricter environmental laws. The former policies tend to promote the expansion of more competitive agriculture linked to export markets, whilst the latter tend to protect forests and local people's forest-dependent livelihoods. The evident tensions between these policies indicate a strong need for greater harmonisation of policies based on a clear understanding of the resulting trade-offs.

\section{Paths of landscape development}

Changing policies and market environments have influenced the development of tropical forest landscapes in Latin America by providing different opportunities to different actor groups. This has resulted in competition both for land and for forest resources - either for management or extraction-between groups and has affected land use patterns. The main characteristics associated with the 5 type of landscapes mentioned in the introduction are summarised in Table 2.

Each landscape identified above represents a specific development path and each is linked to specific ways in which natural, human and financial resources are deployed by actors with diverse social and economic goals. These landscapes should be conceived more as part of a continuum rather than as defined types with distinct boundaries. Furthermore, these landscapes change over time, with competition between actors and land uses, for example, between loggers and indigenous people, cattle ranchers and smallholders in forest-agriculture mosaics, or agribusiness development taking place over grazing lands. Factors exogenous to these landscapes such as market 
and policy changes, as well as endogenous conditions linked to land tenure, power relationships and particular socio-ecological interactions, contribute to defining each landscape change. Often, national policy has favoured agribusiness, cattle ranching and industrial logging at the expense of smallholders and indigenous people. Public policies need to address the specific challenges emerging on these landscapes to deal with their social and economic development needs, whilst ensuring longterm sustainable management of land and forest resources.

\section{Social and ecological outcomes across landscapes}

The development of disparate landscapes has very different social, economic and ecological outcomes (Table 3).

For example, agribusiness development leads to higher deforestation rates, but contributes to significant economic growth and tends to concentrate income among a few medium- and large-scale landholders. Cattle ranching leads to low-productive land uses, because it is often developed through extensive production systems, thus demanding much land and creating few jobs. Peasant agriculture tends to create jobs and local income and often leads to more complex land use mosaics; in some cases, it may lead to wide deforestation depending on population density or demand for specific crops. Indigenous territories protect local livelihoods, but generate few economic benefits and are often located far from markets and social infrastructure. Finally, public production forests are often allocated under concessionary rights, which tend to do less harm to the forests, but concentrate the incomes among a few family groups and timber companies, and do not necessarily lead to forest conservation in the long run.

These landscapes are not static, as mentioned earlier, because of the intense competition between actors, who are variably favoured by global factors and by national and subnational

\section{Box 1. Examples of development trends defining landscape types}

Rapid market-driven growth of agribusiness: Development of large-scale intensive agriculture is not new in Latin America, but it is currently growing to an unprecedented scale in savannahs and tropical forestlands, where there is a relative abundance of land suitable for mechanised agriculture (Grau and Aide 2008). The epicentre of this expansion is Mato Grosso in Brazil, although it has also taken place in lowland Bolivia, northwest Argentina and Paraguay (Grau et al. 2005, Pacheco 2006) because growing demand for soya bean motivated governments to promote the agribusiness sector. Other factors that propelled this expansion were related to relatively low land prices, particularly in the new agricultural frontiers in the forest margins, and the availability of cultivars suited to the cerrado soils developed in Brazil (EMBRAPA SOJA 2008).

Expansion and modernisation of traditional ranching: Cattle raising is practised widely in tropical Latin America in the context of available cheap land and scarcity of labour (da Veiga et al. 2004). Medium- and large-scale traditional cattle ranching dominates in many landscapes in the Brazilian Amazon (e.g. southern Pará, northern Mato Grosso and Rondônia, and in the south of the Amazonas state) (Margulis 2004), and there is a gradual adoption of semi-intensive production systems in those areas with better connections to infrastructure where land becomes scarcer. This is particularly the case in southern Pará and the Transamazon in Brazil (Walker et al. 2000). The expansion of cattle-ranching activities is also a common feature in the rural lands in Andean Amazon countries and Mesoamerica (Etter et al. 2008).

Slow growth of small-scale agriculture: Small-scale agriculture has evolved in the rural tropics in Latin America, embraced by smallholders with production systems ranging from shifting cultivation, to more stable agricultural systems mixing annual (e.g. rice, cassava, maize) and perennial crops (e.g. coffee, cocoa) and livestock production, although in some cases more specialised systems have been implemented (Walker et al. 2002, Pichón et al. 2002). Smallholder agriculture has stabilised in many old colonisation areas (e.g. Bragantina and Transamazon in Pará, Rondônia and northern Santa Cruz in Bolivia), and it is still expanding in new frontier lands (e.g. Bolivia's northern Santa Cruz, Peru's Madre de Dios and Ucayali regions, Colombia's Caquetá and Guaviare provinces and Ecuador's Sucumbíos).

Large-scale commercial logging on public lands: The system of forest concessions is still active in some countries with available public production forest, such as Peru and Bolivia, and in Guatemala with social concessions, although it has ceased in countries whose public production forests have shrunk over time. Brazil has begun to grant some public forests as concessions in the Amazon basin after a process of tenure-rights clarification. Concession logging has been promoted by national natural resource authorities - often with the support of multinational conservation institutions - as a means to promote sustainable management of national production forests, generate national revenues and prevent clear-cutting.

Resurgence of traditional agro-extractive economies: Governments have made progress in attending to several claims for land, which has led to the formal recognition of collective ownership rights by indigenous people over the lands they have traditionally occupied (Roldan 2004). For example, most notably, social claims from indigenous peoples resulted in the delimitation and titling of indigenous lands across many countries in Latin America, and demands from agro-extractive populations led to the creation of 'extractive reserves' in Brazil. Land tenure recognition contributes to securing the access to forest resources of local populations that depend on these resources to make a living, although they still face many institutional and legal barriers to benefiting from formal timber management (Pacheco 2009). 
Table 3. Main social, economic and ecological outcomes in different types of landscapes

\begin{tabular}{|c|c|c|c|c|}
\hline \multirow[t]{2}{*}{ Type of landscape } & \multicolumn{4}{|c|}{ Outcomes associated with landscape type } \\
\hline & Pressure on forests & Economic growth & Distribution of benefits & Access to services \\
\hline $\begin{array}{l}\text { Agricultural lands } \\
\text { dominated by } \\
\text { agribusiness }\end{array}$ & High & $\begin{array}{l}\text { Relatively high, mainly in } \\
\text { soya bean frontiers }\end{array}$ & $\begin{array}{l}\text { Income concentrated } \\
\text { among few landholders }\end{array}$ & $\begin{array}{l}\text { Good, improving } \\
\text { with expansion of } \\
\text { infrastructure }\end{array}$ \\
\hline $\begin{array}{l}\text { Pasture lands } \\
\text { dominated by } \\
\text { extensive cattle } \\
\text { ranching }\end{array}$ & High & $\begin{array}{l}\text { Medium, but varies } \\
\text { depending on location } \\
\text { with respect to markets }\end{array}$ & $\begin{array}{l}\text { Income largely } \\
\text { concentrated among large- } \\
\text { scale landholders }\end{array}$ & Medium to good \\
\hline $\begin{array}{l}\text { Forest-agriculture } \\
\text { mosaics under } \\
\text { diversified land uses }\end{array}$ & Medium to high & $\begin{array}{l}\text { Varies depending on } \\
\text { market conditions of main } \\
\text { crops produced }\end{array}$ & $\begin{array}{l}\text { More equal, but social } \\
\text { differentiation grows over } \\
\text { time }\end{array}$ & $\begin{array}{l}\text { Medium, but there } \\
\text { are large variations }\end{array}$ \\
\hline $\begin{array}{l}\text { Frontier areas with } \\
\text { dominance of } \\
\text { logging }\end{array}$ & $\begin{array}{l}\text { Low, but tend to } \\
\text { grow linked to market } \\
\text { integration }\end{array}$ & $\begin{array}{l}\text { Large in forests with } \\
\text { valuable timber species }\end{array}$ & $\begin{array}{l}\text { Benefits largely } \\
\text { concentrated among few } \\
\text { timber companies }\end{array}$ & Relatively poor \\
\hline $\begin{array}{l}\text { Areas beyond the } \\
\text { agricultural frontier } \\
\text { with local populations }\end{array}$ & Low & $\begin{array}{l}\text { Low, often timber tends } \\
\text { to be the main source of } \\
\text { cash income }\end{array}$ & $\begin{array}{l}\text { Benefits from economic } \\
\text { activities are more equally } \\
\text { distributed }\end{array}$ & Poor \\
\hline
\end{tabular}

policies. This competition is also the result of structural conditions in frontier landscapes, which are associated with land tenure insecurity, uneven market powers and differentiated access to economic and institutional incentives. To promote agricultural development that places less pressure on forests resources and reduces poverty, policies should focus on:

- 'closing the frontier' to reduce land speculation and encroachment on public lands, mainly through land regularisation but primarily attending to the needs of the rural poor;

- managing the expansion of agribusiness, and redirecting it to already deforested lands, and facilitating the development of more inclusive business models with greater benefit sharing;

- stimulating the modernisation of cattle ranching as a way to increase land use efficiency of already occupied lands, whilst supporting more integrated systems of land use management;

- improving economic opportunities for smallholders and indigenous people by supporting their diversified land use and livelihood portfolios, and sources of income;

- $\quad$ promoting sustainable forest management in frontier areas through greater promotion of best practices by timber companies and greater integration of informal loggers.

Whilst state regulations are critical for promoting these changes, it is not clear to what extent REDD+ schemes will stimulate the transformational changes to make this happen. This is because the success of REDD+ will greatly depend on how it deals with the challenges arising from multiple actors' needs and landscape types. Thus, REDD+ can become a crucial mechanism, if resources are available, for supporting the emergence of some landscape types rather than others.

\section{Implications for REDD+ design and implementation}

The diversity of actors and landscapes represents a significant challenge in the design of effective and equitable REDD+ interventions (Angelsen 2008). A main message of this paper is that no 'one-size-fits-all' approach to REDD+ could possibly deliver both cost-effectiveness and social equity because diverse actors shape landscapes in multiple and complex ways, resulting in diverse development pathways. A summary of some of the aspects relevant to the REDD+ debate, such as opportunity costs, tenure and resource access, poverty and governance conditions, is given in Table 4.

Landholders linked to agribusiness have higher land use opportunity costs than indigenous people, whose opportunity costs are relatively low. The former tend to hold relatively large tracts of land under relatively secure conditions. In contrast, rights in frontier areas and particularly rights of smallholders and indigenous people are often informal and less secure. Finally, governance conditions tend to improve in landscapes that have a larger state presence, whilst in remote frontier areas, higher levels of conflict over resources are prevalent.

National policymakers have limited intervention options with which to directly influence land use decisions in forest landscapes. National REDD+ strategies will have to rely heavily on incentive- and disincentive-based policy instruments, such as conditional compensation transfers and improved enforcement of forest use and access regulations (i.e. command-and-control). These strategies have to be tailored, however, according to the landscape type. 
Table 4. Landscape types and key REDD+ design issues

\begin{tabular}{|c|c|c|c|c|c|}
\hline \multirow[t]{2}{*}{ Type of landscape } & \multicolumn{5}{|c|}{ Key characteristics with relevance for REDD+ design } \\
\hline & $\begin{array}{l}\text { Pressure on } \\
\text { forests }\end{array}$ & $\begin{array}{l}\text { Opportunity } \\
\text { costs }\end{array}$ & $\begin{array}{l}\text { Tenure and resource } \\
\text { access }\end{array}$ & $\begin{array}{l}\text { Poverty/ } \\
\text { well-being }\end{array}$ & $\begin{array}{l}\text { Governance } \\
\text { conditions }\end{array}$ \\
\hline $\begin{array}{l}\text { Agricultural lands } \\
\text { dominated by } \\
\text { agribusiness }\end{array}$ & High & High & $\begin{array}{l}\text { Relatively clear ownership } \\
\text { often in a context of } \\
\text { little developed land } \\
\text { administration systems }\end{array}$ & $\begin{array}{l}\text { Generally capitalised } \\
\text { and comparatively } \\
\text { well off }\end{array}$ & $\begin{array}{l}\text { Often farmers are } \\
\text { well organised } \\
\text { and are politically } \\
\text { influential }\end{array}$ \\
\hline $\begin{array}{l}\text { Pasture lands } \\
\text { dominated by } \\
\text { extensive cattle } \\
\text { ranching }\end{array}$ & High & Low & $\begin{array}{l}\text { Not formal ownership } \\
\text { rights but tenures tend } \\
\text { to be secure, although } \\
\text { in some cases claims are } \\
\text { shaky (land grabbing) }\end{array}$ & $\begin{array}{l}\text { Some capitalised } \\
\text { ranchers, but often } \\
\text { medium-income levels }\end{array}$ & $\begin{array}{l}\text { Local elites control } \\
\text { local decision- } \\
\text { making and are } \\
\text { politically influential }\end{array}$ \\
\hline $\begin{array}{l}\text { Forest-agriculture } \\
\text { mosaics under } \\
\text { diversified land } \\
\text { uses }\end{array}$ & $\begin{array}{l}\text { Medium to } \\
\text { high }\end{array}$ & Low to medium & $\begin{array}{l}\text { Often no formal land } \\
\text { ownership but tenure } \\
\text { relatively secure }\end{array}$ & $\begin{array}{l}\text { Both poor and } \\
\text { comparatively wealthy } \\
\text { groups }\end{array}$ & $\begin{array}{l}\text { Strong local } \\
\text { organisations in } \\
\text { some regions, but } \\
\text { often no voice }\end{array}$ \\
\hline $\begin{array}{l}\text { Frontier areas with } \\
\text { dominance of } \\
\text { logging }\end{array}$ & $\begin{array}{l}\text { Low (but } \\
\text { impacts on } \\
\text { degradation) }\end{array}$ & Medium to high & $\begin{array}{l}\text { Formal sector often } \\
\text { engaged in concessions, } \\
\text { but large informal (often } \\
\text { illegal) sector }\end{array}$ & $\begin{array}{l}\text { Capitalised timber } \\
\text { companies, but poor } \\
\text { people linked to the } \\
\text { informal sector }\end{array}$ & $\begin{array}{l}\text { Often disputes on } \\
\text { forest access, and } \\
\text { influential local } \\
\text { elites }\end{array}$ \\
\hline $\begin{array}{l}\text { Areas beyond } \\
\text { the agricultural } \\
\text { frontier with local } \\
\text { populations }\end{array}$ & Low & Low & $\begin{array}{l}\text { Community use and } \\
\text { access rights often well } \\
\text { defined, but not always } \\
\text { secure }\end{array}$ & $\begin{array}{l}\text { Widespread poverty; } \\
\text { little or no access to } \\
\text { public services (few } \\
\text { exceptions) }\end{array}$ & $\begin{array}{l}\text { Local groups } \\
\text { sometimes well } \\
\text { organised, but often } \\
\text { no voice }\end{array}$ \\
\hline
\end{tabular}

Four key design challenges emerge when considering REDD+ across actors and landscapes:

- identifying and targeting key actors and landscapes for REDD+ incentives;

- designing the optimal incentive mix to change the behaviour of these actors;

- embedding REDD+ interventions in existing institutional systems; and

- ensuring participation and benefit capture among poor stakeholders.

Targeting actors and landscapes: Clearly defining the target will determine the extent to which REDD+ can become an effective climate change mitigation measure. Targeting landscapes with dynamic forest cover change would seem to be a natural starting point for pilot action. However, economic (opportunity costs) and institutional (tenure regulation and security) conditions will not always be favourable for the effective delivery of REDD+ incentives on the ground. As a result, decision makers face trade-offs between the potential additionality and the feasibility of targeting early REDD+ action to forest frontiers. That said, the scale of interventions must likely go beyond frontier landscapes to minimise leakage into current low-pressure forest areas and consolidate land use dynamics in agricultural mosaics.
Differentiated incentives: Because landscapes are transformed by diverse, sometimes poor, actors with varying resource strategies, REDD+ policies will have uneven impacts on rural livelihoods. It is clear that land-asset distribution and deforestation patterns will determine how incentives and disincentives of a given REDD+ policy play out in terms of benefit distribution. However, the lack of consensus regarding what represents an equitable distribution of rewards or punishment probably represents the single most important obstacle for REDD+ at the national level (Ricketts et al. 2010). Interestingly, whilst a command-and-control-dominated REDD+ strategy would tend to disproportionately hurt those who have benefited from deforestation in the past, the same actors would become the prime beneficiaries of a compensation-based REDD+ approach (Börner et al. 2010).

Broader institutional systems: Smallholders at remote forest margins, who are generally poor, often have few land use alternatives to shifting cultivation. Without improved access to alternative technologies and income opportunities, commandand-control-based REDD+ could drive some farmers further into poverty, whereas conditional compensation-based REDD+ bears the risk of creating dependencies on external income streams as traditional land use strategies have to be abandoned. Even a careful balance of compensation incentives and commandand-control disincentives, as discussed above, may prove 
insufficient to induce improved land uses. Thus, improved market access, extension services and technical assistance as land administration systems are public efforts that have to be undertaken in addition to REDD+ compensations.

Participation and benefit distribution: Ultimately, the success of REDD+ will depend on the ability of recipient countries' governments to negotiate a fair deal with all land users (Pascual et al. 2010). Rewards to forest stewards with a good track record, such as indigenous and traditional populations, may increase the perceived fairness of REDD+, but would tend to reduce cost-effectiveness as funds would be diverted from areas of high deforestation. This is one of the major trade-offs faced by REDD+ implementers. At the same time, widespread de facto tolerance of illegal forest cover change over many years probably means the compliance of large players will have to be subsidised to some extent. Political bargaining power varies considerably across actor groups. Whilst some smallholders are represented by strong multilevel organisations and indigenous groups are well organised in politically influential umbrella organisations, other traditional population groups such as extractivists often lack the means to influence the national policy debate. Equitable benefit sharing will thus also depend on the ability of social organisations to effectively involve their constituents in the development of national REDD+ strategies.

\section{Conclusions}

Important processes of landscape change are taking place in Latin America due to a greater influence of global markets and infrastructure development, which often lead to increased pressure on forest landscapes. At the same time, however, other policies are leading towards forest conservation, notably the recognition of land claims by indigenous people and other local communities and allocation of forest to conservation aims. These different dynamics have led to the persistence of competing demands for land with different outcomes in land use change, economic growth and people's livelihoods. REDD+ may play an important role in influencing which development paths will prevail in tropical forested landscapes. However, many difficult choices have to be made for REDD+ to work in practice, mainly to balance cost-effectiveness and equity, and to create the institutional conditions necessary to achieve the desired outcomes.

The diversity of trends discussed here indicates that it is reasonable to assume that a 'one-size-fits-all' approach will not work for REDD+ implementation. In some countries, targeting deforestation hotspots at the forest frontier may be feasible only after conflicting land claims have been settled and tenure is well delimited. Whilst REDD+ action must be well targeted, national strategies must remain inclusive and allow for benefits and costs to be shared by various stakeholder groups according to fairness criteria. REDD+ thus goes far beyond the compensation of land users' opportunity costs in high-pressure areas; it also requires addressing some of the underlying structural reasons for overexploitation of resources and underdevelopment in tropical forest areas. Early proponents of REDD+ may have widely underestimated its costs. The potential benefits, however, may extend far beyond climate change mitigation. This depends on whether or not there is enough political will to take the development of the world's forest margins seriously, and involve the diverse populations who depend on forest resources.

\section{References}

Angelsen, A. 2008 Moving ahead with REDD: issues, options and implications. CIFOR, Bogor, Indonesia.

Barham, B.L., Coomes, O.T. and Takasaki, Y. 1999 Rain forest livelihoods: income generation, household wealth and forest use. Unasylva 50(198): 34-42.

Börner, J., Wunder, S., Wertz-Kanounnikoff, S., Tito, M.R., Pereira, L. and Nascimento, N. 2010 Direct conservation payments in the Brazilian Amazon: scope and equity implications. Ecological Economics 69: 1272-1282.

Bray, D.B., Merino-Pérez, L. and Barry, D. 2005 The community forests of Mexico: managing for sustainable landscapes. University of Texas Press, Austin, Texas, USA.

Carr, D.L., Lopez, A.C. and Bilsborrow, R.E. 2009 The population, agriculture and environment nexus in Latin America: country-level evidence from the latter half of the twentieth century. Population Environment 30: 222-246.

Chomitz, K. 2007 Overview at loggerheads? Agricultural expansion, poverty reduction, and environment in the tropical forests. World Bank, Washington, DC.

Da Veiga, J.B., Tourrand, J.F., Piketty, M.G., Poccard-Chapuis, R., Alves, A.M. and Thales, M.C. 2004 Expansão e trajetórias da pecuária na Amazônia. Editora UNB, Brasilia.

Embrapa Soja. 2008 Tecnologias de produção de soja - região central do Brasil 2009 e 2010. Embrapa Soja, Londrina, Para, Brazil.

Etter, A., McAlpine, C. and Possingham, H. 2008 A historical analysis of the spatial and temporal drivers of landscape change in Colombia since 1500. Annals of the Association of American Geographers 98(1): 1-27.

Food and Agriculture Organization (FAO). 2010 Global forest resources assessment 2010. FAO, Rome.

Gibbs, H., Ruesch, A.S., Achard, F., Clayton, M.K., Holmgren, P., Ramankutty, N. and Foley, J.A. 2010 Tropical forests were the primary sources of new agricultural land in the 1980s and 1990s. Proceedings of the National Academy of Sciences doi: 10.1073/pnas.0910275107

Grau, H.R. and Aide, M. 2008 Globalization and land-use transitions in Latin America. Ecology and Society 13(2): 16.

Grau, H.R., Gasparri, N.I. and Aide, T.M. 2005 Agriculture expansion and deforestation in seasonally dry forests of 
northwest Argentina. Environmental Conservation 32(2): 140-148.

Kaimowitz, D. 2008. The prospects for reduced emissions from deforestation and degradation (REDD) in Mesoamerica. International Forestry Review 10(3): 485-495.

Lee, D.R. and Barrett, C.B. (eds.) 2001 Tradeoffs or synergies? Agricultural intensification, economic development and the environment. CAB International Publishing, New York.

Margulis, S. 2004 Causes of deforestation of the Brazilian Amazon. Report No. 22, 107. World Bank, Washington, DC.

Pacheco, P. 2006 Agricultural expansion and deforestation in Lowland Bolivia: the import substitution versus the structural adjustment model. Land Use Policy 23: 205-225.

Pacheco, P. 2009 Agrarian reform in the Brazilian Amazon: its implications for land distribution and deforestation. World Development 37(8): 1337-1347.

Padoch, C., Brondizio, E., Costa, S., Pinedo-Vasquez, M., Sears, R.R. and Siqueira, A. 2008 Urban forest and rural cities: multi-sited households, consumption patterns, and forest resources in Amazonia. Ecology and Society 13(2). http:// www.ecologyandsociety.org/vol13/iss2/art2/.

Pascual, U., Muradian, R., Rodríguez, L.C. and Duraiappah, A. 2010 Exploring the links between equity and efficiency in payments for environmental services: a conceptual approach. Ecological Economics 69(6): 1237-1244.
Pichón, F., Marquette, C., Murphy, L. and Bilsborrow, R. 2002 Endogenous patterns and processes of settler land use and forest change in the Ecuadorian Amazon. In: Wood, C. and Porro, R. (eds.) Deforestation and land use in the Amazon, 241-282. University of Florida Press, Gainesville, Florida, USA.

Ricketts, T.H., Soares-Filho, B., da Fonseca, G.A.B., Nepstad, D., Pfaff, A., Petsonk, A., Anderson, A.B., Boucher, D., Cattaneo, A., Conte, M. et al. 2010 Indigenous lands, protected areas, and slowing climate change. PLoS Biology 8(3): 1-4.

Rigg, J. 2006 Land, farming, livelihoods and poverty: rethinking the links in the rural south. World Development 34: 180-202.

Roldan, R. 2004 Models for recognizing indigenous land rights in Latin America. Biodiversity Series Paper No. 99 World Bank Environment Department, World Bank, Washington, DC.

Walker, R., Moran, E. and Anselin, L. 2000 Deforestation and cattle ranching in the Brazilian Amazon: external capital and household processes. World Development 28(4): 683-699.

Walker, R., Perz, R., Caldas, M. and Silva, L.T. 2002 Land-use and land-cover change in forest frontiers: The role of household life cycles. International Regional Science Review 25(2): 169-199.

This summary was drawn from the following paper 'Landscape transformation in tropical Latin America Assessing trends and policy implications for REDD+', prepared for the Workshop on forest governance, decentralisation and REDD+ in Latin America and the Caribbean, Oaxaca, Mexico. 31 August - 3 September 2010. The workshop was a country-led initiative in support of the United Nations Forum on Forests (UNFF) (http://www.cifor.cgiar.org/Events/Oaxacalist/introduction.htm). The full paper will be published in a special issue of Forests, an open access journal of forestry and forest ecology: http://www.mdpi.com/journal/forests.

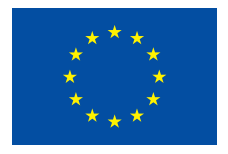

www.cifor.cgiar.org

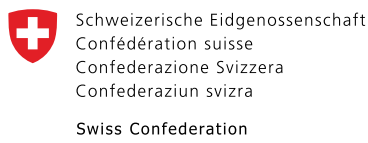

Federal office for the Environment FOEN

\section{Center for International Forestry Research}

CIFOR advances human wellbeing, environmental conservation and equity by conducting research to inform policies and practices that affect forests in developing countries. CIFOR is one of 15 centres within the Consultative Group on International Agricultural Research (CGIAR). CIFOR's headquarters are in Bogor, Indonesia. It also has offices in Asia, Africa 